Special Issue of the 6th International Congress \& Exhibition (APMAS2016), Maslak, Istanbul, Turkey, June 1-3, 2016

\title{
Optimization of Cutting Parameters, Condition and Geometry in Turning AISI 316L Stainless Steel Using the Grey-Based Taguchi Method
}

\author{
G. BASMACI ${ }^{a, *}$ AND M. AY ${ }^{b}$ \\ ${ }^{a}$ Mehmet Akif Ersoy University, Faculty of Engineering and Architecture, 15030, Burdur, Turkey \\ ${ }^{b}$ Marmara University, Faculty of Technology, Department of Mechanical Engineering, 34722, Istanbul, Turkey
}

\begin{abstract}
In this study, experimental optimization of cutting forces, surface roughness and the hardness of material after turning of AISI 316L stainless steel, using conventional and wiper insert cutting tools under dry, $\mathrm{CO}_{2}$ and MQL cutting conditions, is presented. The influences of feed rate, cutting depth, and cooling system on surface roughness, cutting force and material hardness were examined. In order to optimize the turning process, Grey relational analysis optimization method was used. The optimal machinability parameters of AISI 316L stainless steel with coated carbide insert were successfully determined.
\end{abstract}

DOI: 10.12693/APhysPolA.131.354

PACS/topics: 81.05.-t

\section{Introduction}

The steel materials used in the manufacturing industry are becoming more advanced day by day. Stainless steel, is commonly used in a wide range of applications in the manufacturing sector, due to its high mechanical properties, corrosion resistance and low thermal conductivity [1]. Although it is more expensive, compared to other forms of steel, stainless steel is becoming increasingly popular for use in many fields, ranging from food to health, chemistry to electronics, from defense industry to nuclear power plants and automotive to aerospace, due to its superior mechanical properties and unique corrosion resistance [2-4]. Stainless steel is a type of steel which contains $11-18 \%$ of chromium in its composition [5].

Austenitic and ferritic stainless steel is used particularly in machinery and manufacturing industry. These forms of steel fall under the "difficult to machine" materials class with their low thermal conductivity properties. Low thermal conductivity, leads to high shear force, high cutting temperatures, rapid tool wear, produces difficult to break chips, causes chips to bond to the cutting edge and leads to poor surface quality [6]. In addition the energy used for plastic deformation of the workpiece during machine turning is converted to heat and it is well known that heat mostly occurs in the primary deformation zone. However, heat generated during deformation is closely associated with friction and shear force in the tool-chip interface, which vary according to tool geometry and cutting parameters. Tool-chip contact length and therefore tool geometry directly affect tool life and machining efficiency [7].

In recent years, it is possible to come across many experimental studies investigating the effects of cutting

*corresponding author; e-mail: gbasmaci@mehmetakif.edu.tr parameters on shear force and surface roughness, occurring during machining of various forms of stainless steel. In one of these studies, the machinability of AISI 304 and AISI 316 stainless steel with coated cemented carbide cutting tools was investigated and cutting speed was reported as an important parameter for surface roughness $R a$ [8]. In another study, the $F_{c}$ generated during the turning of AISI 304 austenitic stainless steel with TICcoated cutting tool, was theoretically and experimentally evaluated and it was indicated that the theoretical approach could be used with $80 \%$ average accuracy [9]. $R a$ is reported to decrease parallel to the decrease in cutting sound pressure level during the turning of AISI 304 stainless steel at low feed rate and high cutting speeds [10, 11]. In another study, the verification tests conducted according to the optimum cutting parameters for surface roughness and cutting force during turning of austenitic stainless steel, resulted in a $23.4 \%$ improvement [12]. A variance analysis on the $R a$ resulting from the machining of AISI 304 stainless steel, revealed that feed rate had a $51.84 \%$ effect on Ra [13].

Time, volume and efficiency of production are not the only factors that should be taken into consideration in the assessment of success of a production method. Other important considerations must include the effect on the environment and human health. Machine turning applications, which use cooling techniques that respect human health and the environment, have been developed. The performance characteristics of the alternative cooling technique were found to be superior to the conventional cooling techniques [1, 3-22]. The MQL technique which delivers reduced tool wear and improved surface quality thanks to a reduction in the heat generated in the tool-chip and workpiece-chip cutting zone are important results [23]. Liquid nitrogen, and carbon dioxide are also used as alternative cooling systems for the cooling of the cutting zone. A $55 \%$ reduction in edge wear was reported following the use of liquid nitrogen cooling [24]. 
In this study; the effect of feed rate, depth of cut and cooling system on surface roughness and cutting force during machine turning of AISI 316L stainless steel is investigated. Taguchi Grey analysis technique was used in the optimization of the turning process. Furthermore, variance analysis was conducted to determine the effect of each parameter on the results. As a result of this analysis, the effect of feed rate, depth of cut and cooling system on surface roughness and cutting force during machine turning of AISI 316L stainless steel was determined.

\section{Materials and methods}

AISI 316L was used for the purposes of this study. The experiment samples were rod-shaped, $130 \mathrm{~mm}$ in length and $25 \mathrm{~mm}$ in diameter. During the machining process, CNMG $120408 \mathrm{~mm}$ cutting tips, produced by Sandvik company were used. The Johnford TC 35 CNC Fanuc OT, an $x-z$ axis CNC machine was used during the experiment. A perhometer M1 type surface roughness meter, manufactured by Mahr was used in the experiment. Surface roughness can be determined with various parameters according to DIN, ISO, JIN, AISI standards. A KISTLER 9121 dynamometer with KISTLER 5019b type load amplifier and the DynoWare analysis software was used for power measurement during the experiments (Fig. 1).

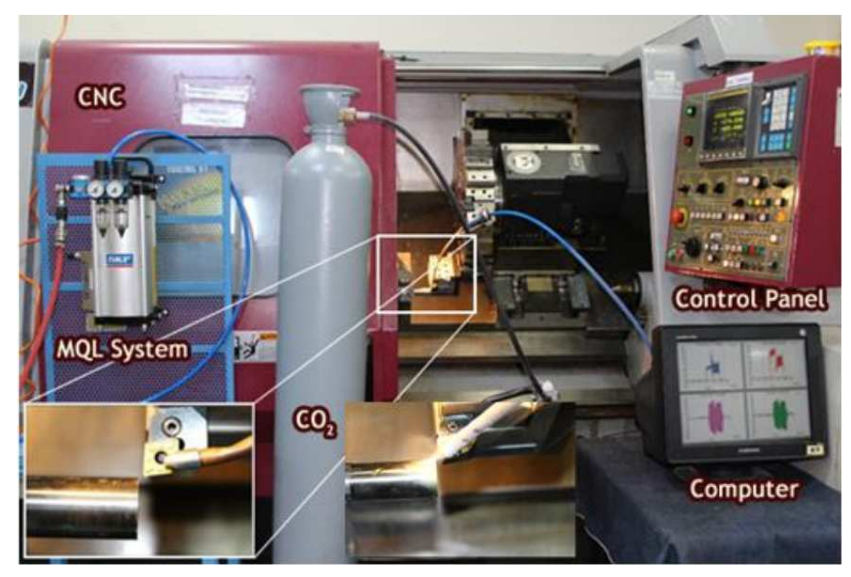

Fig. 1. The experimental setup.

TABLE I

Factors and designated levels.

\begin{tabular}{c|c|c|c}
\hline \hline Factors & Level 1 & Level 2 & Level 3 \\
\hline Feed rate $[\mathrm{mm} / \mathrm{rev}]$ & 0.1 & 0.2 & 0.3 \\
Depth of cut $[\mathrm{mm}]$ & 0.5 & 1 & 1.5 \\
Cooling system & Dry & MQL & $\mathrm{CO}_{2}$
\end{tabular}

Three levels were set between 0.1 to $0.3 \mathrm{~mm} / \mathrm{rev}$ for the feed rate parameter, and 0.5 and $1.5 \mathrm{~mm}$ for depth of cut. Dry, MQL (minimum quantity lubrication) and $\mathrm{CO}_{2}$ options were examined for the cooling system factor.
Table I shows key factors and designated levels, affecting cutting force and surface roughness.

\subsection{Taguchi design}

Taguchi parametric design is a very effective design tool, offering simple and systematic qualitative optimal design at a relatively low cost. It has become very popular in the last two decades. By helping to determine the significant factors, this approach not only saves the experimental time but also the costs. Selection of an orthogonal array is one of the most important steps involved in Taguchi technique. An orthogonal array is a small set of all the possibilities, which helps to determine the least number of experiments. It will further help to conduct experiments to determine the optimum level for each process parameter and to establish the relative importance of individual process parameters [25]. For the experiments performed according to Taguchi L 9 orthogonal array, levels of the set of parameters are given in Table II.

TABLE II

The orthogonal array $\mathrm{L}_{9}$-based surface roughness and cutting force.

\begin{tabular}{c|c|c|c|c|c}
\hline \hline $\begin{array}{c}\text { Exp. } \\
\text { no. }\end{array}$ & Variables & $\begin{array}{c}\text { Surface } \\
\text { roughness, } \\
{[\mu \mathrm{m}](\mathrm{FF})}\end{array}$ & $\begin{array}{c}\text { Surface } \\
\text { roughness, } \\
{[\mu \mathrm{m}](\mathrm{FW})}\end{array}$ & $\begin{array}{c}\text { Cutting } \\
\text { force } \\
{[\mathrm{N}](\mathrm{FF})}\end{array}$ & $\begin{array}{c}\text { Cutting } \\
\text { force } \\
{[\mathrm{N}](\mathrm{FW})}\end{array}$ \\
\hline 1 & $\mathrm{~A}_{1} \mathrm{~B}_{1} \mathrm{C}_{1}$ & 0.618 & 0.532 & 127.861 & 209.621 \\
2 & $\mathrm{~A}_{1} \mathrm{~B}_{2} \mathrm{C}_{2}$ & 0.406 & 0.883 & 235.389 & 305 \\
3 & $\mathrm{~A}_{1} \mathrm{~B}_{3} \mathrm{C}_{3}$ & 0.641 & 1.139 & 394.356 & 417.966 \\
4 & $\mathrm{~A}_{2} \mathrm{~B}_{1} \mathrm{C}_{2}$ & 1.519 & 0.739 & 213.403 & 100.229 \\
5 & $\mathrm{~A}_{2} \mathrm{~B}_{2} \mathrm{C}_{3}$ & 1.493 & 0.562 & 680.935 & 736.619 \\
6 & $\mathrm{~A}_{2} \mathrm{~B}_{3} \mathrm{C}_{1}$ & 1.449 & 1.402 & 559.572 & 659.523 \\
7 & $\mathrm{~A}_{3} \mathrm{~B}_{1} \mathrm{C}_{3}$ & 3.457 & 0.588 & 301.659 & 543.746 \\
8 & $\mathrm{~A}_{3} \mathrm{~B}_{2} \mathrm{C}_{1}$ & 3.694 & 0.967 & 523.654 & 753.211 \\
9 & $\mathrm{~A}_{3} \mathrm{~B}_{3} \mathrm{C}_{2}$ & 3.380 & 0.776 & 708.567 & 701.455
\end{tabular}

\subsection{Taguchi-based Grey relational analysis method}

The obtained experimental results and the determined parameters were optimized with Grey-based Taguchi method. Using regression model, researches were carried out calculating an equation between dependent parameters and independent parameters. The Taguchi method uses a special design of orthogonal arrays to study the entire parameter space with a small number of experiments only.

Experimental design was done using Taguchi method. Hence, it has been possible to reach more comprehensive results with doing less experiment. In this sense, time and money have been used more efficiently [26, 27]. While a single outcome is optimized in the Taguchi method, multiple outcomes can be optimized in a Grey relational analysis [28]. In this study, Taguchi method was used in the experimental design step, Grey relational analysis method was used in the optimization step.

Grey relational analysis optimization process was carried out in the following three steps [28]. 
1. Normalization of experimental results (the lowestthe best).

2. Calculation the Grey relational coefficient.

3. Calculation of the Grey relational degree.

4. Determination of optimal experiment parameters.

In the normalization step, the experimental results were normalized using the following equation according to "the lowest-the best" principle.

$$
x_{i}(k)=\frac{\max y_{i}(k)-y_{i}(k)}{\max y_{i}(k)-\min y_{i}(k)},
$$

where, $x_{i}(k)$ refers to the value at the $i$ th series and $k$ th row after normalization process, $\min y_{i}(k)$ refers to the minimum value of the $i$ th series, $\max y_{i}(k)$ refers to the maximum value of the $i$ th series and $y_{i}(k)$ refers to the original value of the i series at $k$ th row.

In step two, Grey relational coefficient was calculated via Eq. (2)

$$
\xi_{i}(k)=\frac{\Delta \min +\zeta \Delta \max }{\Delta 0_{i}(k)+\zeta \Delta \max } .
$$

Here, $\zeta$ is a distinguishing coefficient between 0 and 1 , $\Delta 0_{i}$ is the amount of deviation between the reference series and the normalization values. $\Delta$ min refers to the minimum value of the deviation sequence from the reference series and $\Delta$ max refers to the maximum value of deviation sequence from the reference series.

In the step three, Grey relational degree was calculated by Eq. (3)

$$
\gamma_{i}=\frac{1}{n} \sum_{k-1}^{n} \xi_{i}(k) .
$$

\section{Results and discussion}

Influence of the cutting parameters and the effect of cutting geometry and parameters on surface roughness $R a$ and cutting force on turning of a AISI 316L stainless steel with Sandvik CNMG 120408 conventional (FF) and wiper $(\mathrm{FW})$ inserts is discussed in this section.

\subsection{Optimization of experimental results for surface roughness and cutting force}

Values of surface roughness and cutting force obtained in the experimental step, for Taguchi L $\mathrm{L}_{9}$ experiment design, are shown in Table II. Grey relational analysis method was applied to the experimental results, as shown in Table III and the other steps (normalization, delta values, and Grey relational grade) results are given in Table IV and Table V.

\begin{tabular}{|c|c|c|c|c|c|c|c|c|}
\hline \multirow{3}{*}{$\begin{array}{l}\text { Exp. } \\
\text { no. }\end{array}$} & \multirow{3}{*}{$\begin{array}{c}\text { Cutting } \\
\text { force } \\
{[\mathrm{N}]}\end{array}$} & \multirow{3}{*}{$\begin{array}{c}\text { Surface } \\
\text { roughness } \\
{[\mu \mathrm{m}]}\end{array}$} & \multicolumn{2}{|c|}{ Normalized data } & \multicolumn{2}{|c|}{ Delta values } & \multirow{2}{*}{\multicolumn{2}{|c|}{$\begin{array}{c}\text { Grey relational } \\
\text { grade }\end{array}$}} \\
\hline & & & \multirow{2}{*}{$\begin{array}{c}\text { Cutting } \\
\text { force }\end{array}$} & \multirow{2}{*}{$\begin{array}{c}\text { Surface } \\
\text { roughness }\end{array}$} & \multirow{2}{*}{$\begin{array}{l}\text { Cutting } \\
\text { force }\end{array}$} & \multirow{2}{*}{$\begin{array}{c}\text { Surface } \\
\text { roughness }\end{array}$} & & \\
\hline & & & & & & & values & rank \\
\hline 1 & 127.861 & 0.618 & 1.000 & 0.907 & 0.000 & 0.093 & 0.922 & 1 \\
\hline 2 & 235.389 & 0.406 & 0.806 & 1.000 & 0.194 & 0.000 & 0.860 & 2 \\
\hline 3 & 394.356 & 0.641 & 0.518 & 0.897 & 0.482 & 0.103 & 0.669 & 4 \\
\hline 4 & 213.403 & 1.519 & 0.845 & 0.514 & 0.155 & 0.486 & 0.635 & 3 \\
\hline 5 & 680.935 & 1.493 & 0.000 & 0.525 & 1.000 & 0.475 & 0.423 & 6 \\
\hline 6 & 559.572 & 1.449 & 0.219 & 0.544 & 0.781 & 0.456 & 0.457 & 7 \\
\hline 7 & 301.659 & 3.457 & 0.686 & 0.104 & 0.314 & 0.896 & 0.486 & 5 \\
\hline 8 & 523.654 & 3.694 & 0.284 & 0.000 & 0.716 & 1.000 & 0.372 & 8 \\
\hline 9 & 708.567 & 3.380 & 0.077 & 0.137 & 0.923 & 0.863 & 0.359 & 9 \\
\hline
\end{tabular}

TABLE III

Normalized data, delta values and Grey relational grade for conventional insert tool.

\begin{tabular}{|c|c|c|c|c|c|c|c|c|}
\hline \multirow{3}{*}{$\begin{array}{c}\text { Exp. } \\
\text { no. }\end{array}$} & \multirow{3}{*}{$\begin{array}{c}\text { Cutting } \\
\text { force } \\
{[\mathrm{N}]}\end{array}$} & \multirow{3}{*}{$\begin{array}{c}\text { Surface } \\
\text { roughness } \\
{[\mu \mathrm{m}]}\end{array}$} & \multicolumn{2}{|c|}{ Normalized data } & \multicolumn{2}{|c|}{ Delta values } & \multirow{2}{*}{\multicolumn{2}{|c|}{$\begin{array}{l}\text { Grey relational } \\
\text { grade }\end{array}$}} \\
\hline & & & \multirow{2}{*}{$\begin{array}{l}\text { Cutting } \\
\text { force }\end{array}$} & \multirow{2}{*}{$\begin{array}{c}\text { Surface } \\
\text { roughness }\end{array}$} & \multirow{2}{*}{$\begin{array}{l}\text { Cutting } \\
\text { force }\end{array}$} & \multirow{2}{*}{$\begin{array}{c}\text { Surface } \\
\text { roughness }\end{array}$} & & \\
\hline & & & & & & & values & rank \\
\hline 1 & 209.621 & 0.532 & 0.832 & 1.000 & 0.168 & 0.000 & 0.875 & 1 \\
\hline 2 & 305 & 0.883 & 0.686 & 0.597 & 0.314 & 0.403 & 0.584 & 2 \\
\hline 3 & 417.966 & 1.139 & 0.513 & 0.302 & 0.487 & 0.698 & 0.462 & 3 \\
\hline 4 & 100.229 & 0.739 & 1.000 & 0.762 & 0.000 & 0.238 & 0.839 & 4 \\
\hline 5 & 736.619 & 0.562 & 0.025 & 0.966 & 0.975 & 0.034 & 0.637 & 5 \\
\hline 6 & 659.523 & 1.402 & 0.143 & 0.000 & 0.857 & 1.000 & 0.351 & 6 \\
\hline 7 & 543.746 & 0.588 & 0.321 & 0.936 & 0.679 & 0.064 & 0.655 & 7 \\
\hline 8 & 753.211 & 0.967 & 0.000 & 0.500 & 1.000 & 0.500 & 0.417 & 8 \\
\hline 9 & 701.455 & 0.776 & 0.079 & 0.720 & 0.921 & 0.280 & 0.496 & 9 \\
\hline
\end{tabular}

TABLE IV

Normalized data, delta values and Grey relational grade for wiper insert tool. 
The Grey relational coefficients were calculated using Eq. 2 and results are shown in Table V.

\section{TABLE V}

Grey relational degrees of the factor levels for conventional insert tool.

\begin{tabular}{c|c|c|c}
\hline \hline Levels & $\begin{array}{c}(\mathrm{A}) \\
\text { Feed rate } \\
{[\mathrm{mm} / \mathrm{rev}]}\end{array}$ & $\begin{array}{c}(\mathrm{B}) \\
\text { Depth of cut } \\
{[\mathrm{mm}]}\end{array}$ & $\begin{array}{c}(\mathrm{C}) \\
\text { Cooling system }\end{array}$ \\
\hline Level 1 & 0.817 & 0.681 & 0.584 \\
Level 2 & 0.505 & 0.552 & 0.618 \\
Level 3 & 0.406 & 0.495 & 0.526
\end{tabular}

The Grey relational degrees related to each experimental result were calculated and the experimental results were ranked in order from highest Grey relational degree and are presented in Fig. 2, Table V and VI.

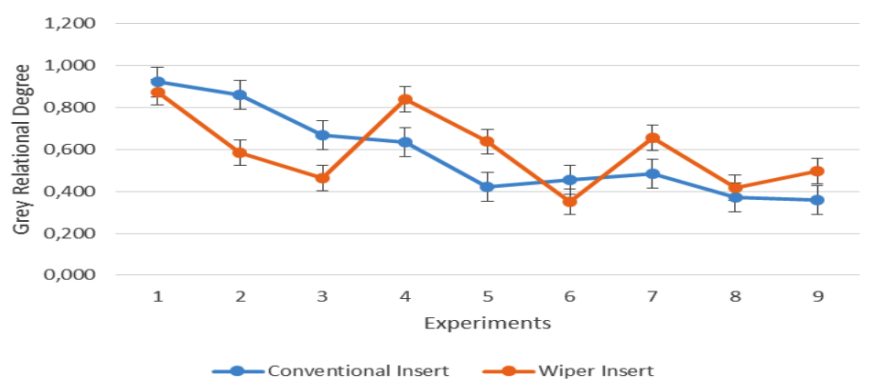

Fig. 2. Grey relational degrees for each experiment.

TABLE VI

Grey relational degrees of the factor levels for wiper insert tool.

\begin{tabular}{c|c|c|c}
\hline \hline Levels & $\begin{array}{c}(\mathrm{A}) \\
\text { Feed rate } \\
{[\mathrm{mm} / \mathrm{rev}]}\end{array}$ & $\begin{array}{c}(\mathrm{B}) \\
\text { Depth of cut } \\
{[\mathrm{mm}]}\end{array}$ & $\begin{array}{c}(\mathrm{C}) \\
\text { Cooling system }\end{array}$ \\
\hline Level 1 & 0.640 & 0.789 & 0.547 \\
\hline Level 2 & 0.609 & 0.546 & 0.640 \\
Level 3 & 0.523 & 0.436 & 0.585
\end{tabular}

As seen from the Table $\mathrm{V}$ and VI, A1 (feed rate: $0.1 \mathrm{~mm} / \mathrm{rev}$ ), B1 (depth of cut: $0.5 \mathrm{~mm}$ ), and C2 (MQL) were selected as the optimal parameter levels. The optimal parameters levels will represent the lowest surface roughness and cutting force value.

\section{Conclusions}

This study of the machinability of AISI $316 \mathrm{~L}$ stainless steel alloy material with SANDVIK CNMG 1204 08 coated conventional $(\mathrm{FF})$ and wiper $(\mathrm{FW})$ inserts has produced useful results. The considered criteria for the machinability were surface roughness, cutting force and material hardness. Three control factors, which were considered to be effective in creating the most suitable conditions for the criteria (feed rate, depth of cut and corner radius) were chosen at three different levels and applied in the experimental study. Below is the summary of the results:

- Based on the Grey relational analysis, the optimal cutting parameters were $\mathrm{A} 1 \mathrm{~B} 1 \mathrm{C} 2$ for surface roughness and cutting force, i.e. feed rate of $0.1 \mathrm{~mm} / \mathrm{rev}$, depth of cut of $0.5 \mathrm{~mm}$ and MQL cooling system.

- Taguchi method is beneficial for the experimental design of the machinability of AISI 316L stainless steel alloy. Having optimized the parameters is also fruitful for keeping the response values at required levels.

- Test results prove the effectiveness of the wiper inserts in providing excellent surface roughness. The results also suggest that the use of the wiper insert is an effective way, which significantly increases cutting efficiency, without changing the machined surface roughness in high feed turning operations.

\section{References}

[1] T. Kosa, P. Ronald, Handbook: Machining, Vol. 16, 9th ed., 1989.

[2] R. M'Saoubi, J.C. Outeiro, B. Changeux, J.L. Lebrun, A.M. Dias, J. Mater. Proc. Tech. 96, 225 (1999).

[3] J.D. Darwin, D.M. Lal, G. Nagarajan, J. Mater. Proc. Tech. 195, 241 (2008).

[4] J.C. Outeiro, D. Umbrello, R. M'Saoubi, Int. J. Mach. Tools Manufact., 46, 1786 (2006).

[5] B.K. Agrawal, Introduction to Engineering Materials, Mc Graw-Hill, 1983.

[6] C. Maranhao, J.P. Davim, Simulation Modelling Practice and Theory 18, 139 (2010).

[7] I. Korkut, M. Boy, I. Karacan, U. Seker, Mater. Design 28, 2329 (2007).

[8] İ. Ciftci, Tribol. Int. 39, 565 (2006).

[9] Ö. Tekaslan, N. Gerger, M. Günay, U. Şeker, Pamukkale Üniversitesi Mühendislik Bilimleri Dergisi 13, 135 (2007).

[10] Z. Tekiner, S. Yeşilyurt, Mater. Design 25, 507 (2004).

[11] M. Kaladhar, K.V. Subbaiah, C.S. Rao, J. Engin. Sci. Technol. 8, 165 (2013).

[12] S. Li, Y. Liu, R. Zhu, H. Li, W. Ding, Appl. Mech. Mater. 34, 1829 (2010).

[13] D.P. Selvaraj, P. Chandramohan, J. Engin. Sci. Technol. 5, 293 (2010).

[14] A.E. Diniz, J.R. Ferreira, F.T. Filho, Int. J. Mach. Tools Manufact. 43, 317 (2003).

[15] H.A. Kishawy, M. Dumitrescu, E.G. Ng, M.A. Elbestawi, Int. J. Mach. Tools Manufact. 45, 219 (2005).

[16] N.R. Dhar, M. Kamruzzaman, M. Ahmed, J. Mat. Proc. Technol. 172, 299 (2006). 
[17] F. Itoigawa, T.H.C. Childs, T. Nakamura, W. Belluco, Wear 260, 339 (2006).

[18] N.R. Dhar, M.W. Islam, S. Islam, M.A.H. Mithu, J. Mater. Proc. Tech. 171, 93 (2006).

[19] E.O. Ezugwu, J. Bonney, R.B. Da Silva, O. Çakir, Int. J. Mach. Tools Manufact. 47, 884 (2007).

[20] A. Attanasio, M. Gelfi, C. Giardini, C. Remino, Wear 260, 333 (2006).

[21] C. Bruni, A. Forcellese, F. Gabrielli, M. Simoncini, Int. J. Machine Tools Manufact. 46, 1547 (2006).

[22] K. Venkatesan, R. Ramanujam, V. Saxena, N. Chawdhury, V. Choudhary, J. Engin. Appl. Sci. 9, 250 (2014).
[23] J. Liu, R. Han, Y. Sun, Int. J. Mach. Tools Manufact. 45, 687 (2005).

[24] M. Stanford, P.M. Lister, C. Morgan, K.A. Kibble, J. Mat. Proc. Technol. 209, 961 (2009).

[25] P.J. Ross, Taguchi Techniques for Quality Engineering, 1996.

[26] N. Tosun, Int. J. Adv. Manufact. Technol. 28, 450 (2006).

[27] İ. Asiltürk, S. Neşeli, Measurement 45, 785 (2012).

[28] M. Kurt, S. Hartomacioğlu, B. Mutlu, U. Köklü, Mater. Technol. 46, 205 (2012). 